\title{
ANALYSIS OF ICT COMPANIES' NEEDS FOR THE ENHANCEMENT OF ICT HIGHER EDUCATION AT MASTER LEVEL: THE CASE OF KAZAKHSTAN
}

\author{
Andreas Ahrens' ${ }^{1}$, Jelena Zascerinska², Saule Amanzholova ${ }^{3}$, \\ Gulnara Zakirova ${ }^{3}$, Ludmila Aleksejeva ${ }^{2}$ \\ ${ }^{1}$ Dr.-Ing. habil., professor, Hochschule Wismar, Wismar, Germany, \\ e-mail: andreas.ahrens@hs-wismar.de \\ ${ }^{2}$ Dr. Paed., leading researcher, Centre for Education and Innovation Research, Riga, \\ Latvia, e-mail: iizi.info@inbox.lv \\ 3 Dr., assistant professor, International Information Technology University, Almaty, \\ Kazakhstan, e-mail: shokataeva@gmail.com \\ ${ }^{3}$ Dr., associated professor, International Information Technology University, Almaty, \\ Kazakhstan, e-mail: g.zakirova@iitu.kz \\ 2 MA, researcher, Centre for Education and Innovation Research, Riga, Latvia, \\ e-mail: asava@inbox.lv
}

Received: 18 June 2020 / Revised: 3 July 2020 /Accepted: 22 July 2020 /

Published: 30 November 2020

\begin{abstract}
The correspondence between ICT master programmes and requirements of ICT companies is shaped via needs analysis. The research aim: The aim of the present paper is to analyse the empirical results of the study of needs of ICT companies, underpinning the elaboration of implications on ICT master programmes. The primary methods used: Exploratory research has been implemented within the present work. The representatives of four ICT companies, namely CISCO, KAIB, Kaspersky Lab and Soft Com, took part in the focus group interview organised at International Information Technology University, Almaty, Kazakhstan, in October 2019. A brief description of the main research results: The theoretical findings of the present research allow concluding that ICT companies and the universities belong to the local or regional community. The structuring content analysis allows identifying the areas of universities-companies cooperation, namely academic staff training, students' training, provision of universities with modern equipment, joint elaboration of the content of ICT master programmes, organisation of joint laboratories including virtual laboratories, ensuring practice and internships for students, etc. The summarising content analysis highlights the need in cooperation between universities and companies to strengthen the sustainable development of the digital economy in the region. The novelty of the present work is formulated in the implications on ICT master programmes. Directions of further research are formulated.
\end{abstract}

Keywords: community, digital economy, ICT companies, ICT higher education, master level, needs analysis, regional development.

JEL code: I23, I25.

\section{Introduction}

The scientific problem reflected in the paper is formulated as the research question: What are implications of ICT companies' requirements on ICT master programmes? The aim of the present paper is to analyse the

http://dx.doi.org/10.17770/jresd2020vol1.12.5389 This is an open access article under the Creative Commons Attribution 4.0 International License 
empirical results of the study of needs of ICT companies, underpinning the elaboration of implications on ICT master programmes.

The tasks/objectives of the research are:

- To define needs analysis and the perspective of ICT companies in needs analysis.

- To carry out an empirical study on needs of ICT companies.

- To elaborate implications on ICT master programmes.

- To draw conclusions.

The novelty of the present work is expressed in the formulated implications on ICT master programmes.

Research methods applied include the use of theoretical as well as empirical methods. Theoretical methods imply analysis of theoretical sources and theoretical modelling (Ahrens, Zascerinska, Melnikova, 2019). The empirical study was based on the focus group interview conducted with the representatives of ICT companies in Kazakhstan. The focus group interview served as the basis for data collection.

The present research employs the qualitative methodology or, in other words, the course of the research and empirical study as content analysis is a qualitative process (Krippendorff, 2004). Qualitative process is a methodology mostly used within the interpretive approach (Thanh, Thanh, 2015).

The interpretive research paradigm has been used in the study. The core of this paradigm is human experience, people's mutual everyday interaction that tends to understand the subjectivity of human experience (Lūka, 2007). The interpretive paradigm is characterized by the researcher's practical interest in the research question (Cohen, Manion, \& Morrison, 2003). The researcher is the interpreter (Ahrens, Purvinis, Zascerinska, Miceviciene, Tautkus, 2018).

Exploratory research is aimed at generating new questions and hypothesis (Phillips, 2006). The exploratory methodology of the empirical study proceeds from exploration in Phase 1 through analysis in Phase 2 to hypothesis/research question development in Phase 3 (Ahrens, Bassus Zascerinska, 2013) as shown in Figure 1 (Ahrens, Foerster, Zaščerinska, Wasser, 2020).

Exploratory methodology

Phase 1

Exploration

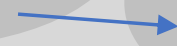

Phase 2

Analysis
Phase 3

Hypothesis/ Question

Development

Fig. 1. Three phases of the exploratory methodology (Ahrens, Foerster, Zaščerinska, Wasser, 2020) 
A focus group interview within the present study is the method of data collection, as focus groups interviews examine how knowledge, and more importantly, ideas, develop and operate within a given cultural context as well as explore exactly how the opinions are constructed (Kitzinger, 1995). The choice of participants for a focus group interview is based on three criteria (Zaščerinska, Aleksejeva, Aḷeksejeva, Gloṇina, Zaščerinskis, Andreeva, 2015) as illustrated in Figure 2:

- participant's knowledge on a given topic,

- participant's cultural difference and education's diversity (occupation, training, etc.) and

- participant's hierarchy in the group.

Choice of participants
for a focus group interview

Participant's

knowledge on

a given topic
Participant's cultural

difference and

education's

diversity
Participant's

hierarchy in the group

Fig. 2. The choice of participants for a focus group interview (compiled by the authors)

The number of participants depends on the heterogeneity of the focus group: the greater the heterogeneity of the group, the fewer the number of participants (Okoli, Pawlovski, 2004). Smaller groups show greater potential (Krueger, Casey, 2000). Thus, four is a good number of participants for the study.

The present focus group was composed of ICT companies' representatives in October 2019. The representatives of such four companies as CISCO, KAIB, Kaspersky Lab and Soft Com took part in the interview at International Information Technology University in Almaty, Kazakhstan. What is interesting that CISCO and Kaspersky Lab were represented by female representatives, and KAIB and Soft Com- by male representatives. In order to save the information of the present research confidential, the respondent's names and surnames are not revealed. 
A non-structured or, in other words, unstructured interview was implemented to search for the main categories of the research field (Kroplijs, Rascevka, 2004). A non-structured interview is conventionally built on a certain topic to be disclosed during the meeting. However, a non-structured interview does not imply any specific set of predetermined questions. A nonstructured interview is organised in a non-formal manner and tends to be open-ended.

The non-structured interview was studied via a content analysis. Further on, a content analysis included such types as (Mayring, 2000)

- structuring content analysis,

- summarizing content analysis.

Structuring content analysis assists in categorising the data in accordance to the previously determined criteria (Budde, 2005). In turn, summarizing content analysis seeks to reduce the material in such a way that the essential contents are preserved, but a manageable short text is produced (Mayring, 2004).

The enabling study question (hypothesis) is formulated as following: What do ICT companies expect from ICT master programmes?

\section{Research results and discussion}

The contemporary development of the world economy, on the one hand, focuses on the concept of digital economy (Ahrens, Foerster, Zaščerinska, Wasser, 2020). On the other hand, the digital economics is increasingly becoming the economy itself (OECD, 2014). The regional economy and development, that are inter-related (Ahrens, Gruenwald, Zaščerinska, Amanzholova, Aleksejeva, 2019) as shown in Figure 3, have to be embedded into the national and global digital economic structures as well.

Regional economy
Regional development

\section{Fig. 3. The relationship between the regional economy and regional development (compiled by the authors)}

Sustainable regional development as well as the economics are strengthened via building university capacity (Ahrens, Gruenwald, Zaščerinska, Amanzholova, Aleksejeva, 2019). One of the ways for building university capacity is to design and implement modern Information and Communication Technologies (ICT) master programmes (Ahrens, 
Gruenwald, Zaščerinska, Amanzholova, Aleksejeva, 2019) as demonstrated in Figure 4.

\section{Sustainable regional \\ development and the economy}

Building university capacity

\section{ICT master programmes}

Fig. 4. The relationship between sustainable regional development and the economy, building university capacity and ICT master programmes (compiled by the authors)

These ICT master programmes have to satisfy the requirements of ICT companies in which the graduates will work.

The correspondence between ICT master programmes and requirements of ICT companies is shaped via needs analysis as depicted in Figure 5.

\section{Needs analysis}

ICT master programmes
Requirements of

ICT companies

Fig. 5. The relationship between needs analysis, ICT master programmes and requirements of ICT companies (compiled by the authors)

Needs have to be permanently monitored (Ahrens, Gruenwald, Zaščerinska, Amanzholova, Aleksejeva, 2019). Conventionally, needs analysis is proposed to be carried out from four perspectives (Zaščerinska, Melnikova, Ahrens, 2020) as depicted in Figure 6 (Ahrens, Foerster, Zaščerinska, Wasser, 2020), namely

- experts'view,

- students' view,

- teaching staff view, and

- community view. 


\section{Needs analysis}

Experts view

Students' view

Educators' view

Community' view

Fig. 6. Four perspectives of needs analysis

(Ahrens, Foerster, Zaščerinska, Wasser, 2020)

ICT companies belong to the community, as by community, state's government, local government, non-governmental organisations and all the other interested organisations as well as persons are meant (Ahrens, Foerster, Zaščerinska, Wasser, 2020). Further on, the ICT companies, invited for the focus interview, were characterized by an essential feature of a community, namely common identity (Piebalga, Zvaigzne, 2019). Common identity is characterised (Piebalga, Zvaigzne, 2019) by a common sense of belonging to the locality, human relationships, the environment, culture and values.

A perspective is represented by a view (Ahrens, Foerster, Zaščerinska, Wasser, 2020). A view is identified as an individual's opinion based on his/her knowledge, skills and attitudes to a phenomenon (Ahrens, Zaščerinska, Hariharan, Andreeva, 2016).

The CISCO representative stressed the importance of the learning portfolio for people willing to collaborate with CISCO in the area of Networking, Security, IoT \& Analytics, OS \& IT, Programming, Business and Digital Literacy. CISCO also offers community partnerships for institutions to deliver curricula that extend beyond educational training and include the problem-solving and entrepreneurial skills students need to get a job or create their own businesses. Another such point was highlighted by the CISCO representative as certification of students' abilities to design, implement and protect secure networks.

The representative from Kaspersky Lab emphasized the significance of training courses for the academic staff of ICT master programmes. The proposal of training courses included Basics of Information Security, Legal Responsibility for Cyber Incidents, and Automated Systems.

The representative from Kaspersky Lab also offered free access to all the facilities as well as official release for software required for the practical part of the training courses at universities in Kazakhstan in case if the equipment 
is installed in one university that is specialized in ICT, namely International Information Technology University, Almaty, Kazakhstan.

The KAIB represents the association of about 20 ICT companies in Kazakhstan. According to the KAIB representative, many ICT companies lack the legislative basis in assuring the quality of ICT products and services. No common terminology was developed. For example, such terms as "password", "code" and "login" are used synonymously. The KAIB representative pointed that ICT becomes outdated after four-five years. He expressed the idea of the establishment of scientific and practical centres or laboratories in order to prepare master students for the employment in the field of ICT. His idea was that the virtual laboratory should be jointly established with other universities in Kazakhstan that focus on teaching ICT master students. From the experience of the KAIB association, programming and the use of these developed programmes are done by different specialists. Different specialists have different approaches to the use of the programmes developed. That is why the programmes require permanent adjustment and updates. The joint laboratory will allow solving the problem of discrepancies between programming and use these programmes. He also suggested that academic staff should have a working experience in the ICT industry. Every year KAIB offers practical training for 30 ICT students. Together with this, he admitted that ICT master students might need an employer's competencies.

The Soft Com representative was concerned about the lack of the legislative basis in Kazakhstan for information collection, storage and processing. He pointed that technical equipment is vulnerable that does not allow securing information. He opined out that Kazakhstan lacks information analysts.

The findings of the empirical study carried out demonstrate that the ICT companies as well as the universities belong to the local or regional community. The ICT companies need cooperation with the academic staff and students of universities involved in the implementation of ICT higher education at master level in order to help companies meet the challenges of digital transformation in the era of digital economy. Another finding of the empirical study is that female representatives of the ICT companies focused mostly on training opportunities, while male representatives - on a wider spectrum of challenges such as common terminology development, organisation of centres, laboratories, internships, and other issues ICT companies face in Kazakhstan.

The structuring content analysis allows identifying such areas of universities-companies cooperation as:

- academic staff training,

- students' training,

- provision of universities with modern equipment, 
- joint elaboration of the content of ICT master programmes,

- organisation of joint laboratories including virtual laboratories,

- ensuring practice and internships for students, etc.

The summarising content analysis highlights the need in cooperation between universities and companies to strengthen the sustainable development of the digital economy in the region.

\section{Conclusions and suggestions}

The theoretical findings of the present research allow concluding that the ICT companies as well as the universities belong to the local or regional community.

The findings of the empirical study allow drawing the conclusion on willingness of ICT companies and universities in cooperation for fostering sustainable development of the digital economy in the region. The finding of the empirical study is the focus of female representatives of the ICT companies mostly on training opportunities, while male representatives - on technical and technological issues ICT companies face in Kazakhstan.

The areas of universities-companies cooperation have been identified. The areas of universities-companies cooperation serve as the implications on ICT master programmes in this work. Implications on ICT master programmes include regional universities-companies cooperation in:

- academic staff training,

- students' training,

- provision of universities with modern equipment,

- joint elaboration of the content of ICT master programmes,

- organisation of joint laboratories including virtual laboratories,

- ensuring practice and internship for students, etc.

The present research has limitations. The inter-connections between needs analysis, community and university-company cooperation have been set. Another limitation is the empirical study conducted in involving the respondents of a focus group interview only. Therefore, the results of the study cannot be representative for the whole area. Nevertheless, the results of the research - such as the areas of universities-companies cooperation may be used as a basis of analysis of universities-companies cooperation in other countries. If the results of other countries had been available for analysis, different results could have been attained. There is a possibility to continue the study.

The further research will focus on the involvement of more respondents into the empirical study. A comparative study of needs analysis from four perspectives, namely experts' perspective, students' perspective, teaching staff perspective, and community perspective, will be carried out. A 
comparative study of needs of ICT companies in different countries could be of a great research interest, too.

\section{References}

1. Ahrens, A., Bassus, O., Zaščerinska, J. (2013). Bi-professional Curriculum in Higher Education: Context Analysis. Proceedings of 6th ICEBE International Conference on Engineeirng and Business Education Innovation, Entrepreneurship and Sustainability, Windhoek, Namibia, 7 - 10 October, 101-107.

2. Ahrens, A., Foerster, M., Zaščerinska, J., Wasser, I. (2020). European Accreditation Agency's View on Kazakhstan's Engineering and Information Technology Higher Education. SOCIETY. INTEGRATION. EDUCATION. Proceedings of the International Scientific Conference, V, 15-25. http://dx.doi.org/10.17770/sie2020vol1.4861

3. Ahrens, A., Gruenwald, N., Zaščerinska, J., Amanzholova, S., Aleksejeva, L. (2019). Building University Capacity in the Field of ICT Education at Master Level For Strengthening Regional Development and Economics: The Case of Kazakhstan. 9-th International Scientific Conference «Perspectives of Economic of Kaliningrad Region and EU Development», Scientific Printed Words of the Conference, 10-13.

4. Ahrens, A., Purvinis, O., Zaščerinska, J., Miceviciene, D., Tautkus, A. (2018). Burstiness Management for Smart, Sustainable and Inclusive Growth: Emerging Research and Opportunities. IGI Global. DOI: 10.4018/978-1-5225-5442-4

5. Ahrens, A., Zaščerinska, J., Melnikova, J. (2019). Method for the Construction of Students' Scientific Identity within English for Academic Purposes: The Case of International Students of Master Programme "Information and Electrical Engineering" at Hochschule Wismar. SOCIETY. INTEGRATION. EDUCATION. Proceedings of the International Scientific Conference, I, 43-53. DOI: http://dx.doi.org/10.17770/sie2019vol1.3731

6. Ahrens, A., Zascerinska, J., Hariharan, R., Andreeva, N. (2016). Educators' Opinion on Webinars in Higher Education. Proceedings of the International Scientific Conference SOCIETY. INTEGRATION. EDUCATION, I, 15-27. DOI: http://dx.doi.org/10.17770/sie2016vol1.1488

7. Budde, R. (2005). Mexican and Central American L.A. Garment Workers: Globalized Industries and their economic constraints. LIT Verlag Münster.

8. Cohen, L., Manion, L., Morrsion, K. (2003). Research Methods in Education. London and New York: Routledge/Falmer Taylor \& Francis Group.

9. Kitzinger, J. (1995). Education and debate Qualitative Research: Introducing focus groups. BMJ, 311, 299-302.

10. Krippendorff, K. (2004). Content Analysis. An Introduction to its Methodology. London: SAGE Publications.

11. Kroplijs, A., Rascevska, M. (2004). Kvalitatīvās pētniecības metodes sociālajās zinātnēs. Rīga: RaKa.

12. Krueger, R. A. \& Casey, M. A. (2000). Focus Groups: A Practical Guide for Applied Research (3rd ed.) Thousand Oaks, CA: Sage Publications.

13. Lūka, I. (2007). Development of Students' ESP Competence in Tourism Studies at Tertiary Level. Unpublished dissertation. Rīga: Latvijas Universitāte.

14. Mayring, P. (2000). Qualitative Content Analysis. Forum Qualitative Sozialforschung, $1(2)$, Art. 20.

15. Mayring, P. (2004). Qualitative Content Analysis. In: U. Flick, E. Von Kardoff and I. Steinke (Eds). A Companion to Qualitative Research, SAGE, UK, Glasgow, 266-269. 
16. Okoli, C., Pawlovski, S. (2004). The Delphi Method as a Research Tool: an example, design considerations and applications. Information and Management, 42(1), 15-29.

17. Organization for Economic Co-operation and Development (OECD). (2014). Addressing the Tax Challenges of the Digital Economy. OECD 2014.

18. Phillips, D. (2006). Comparative Education: method. Research in Comparative and International Education, 1(4), 304-319.

19. Piebalga, E., Zvaigzne, A. (2019). Theoretical Aspects of the Concept of Community in the Context of Social Sciences. Latgale National economy research Journal of Social Sciences, 1(11), 78-85. http://dx.doi.org/10.17770/lner2019vol1.11.4244.

20. Thanh, N.C., Thanh, T.T.L. (2015). The Interconnection Between Interpretivist Paradigm and Qualitative Methods in Education. American Journal of Educational Science, 1(2), 24-27.

21. Zaščerinska, J., Al̦eksejeva, A., Al̦eksejeva, L., Gloṇina, O., Zaščerinskis, M., Andreeva, N. (2015). Formal Adult Education in Latvia: Focus Group Interview. In O. Clipa \& G. Cramariuc (eds.), Educatia in societatea contemporana. Aplicatii, 287-294. Iasi, Romania: Editura LUMEN. ISBN: 978-973-166-409-5.

22. Zaščerinska, J., Melnikova, J., Ahrens, A. (2020). Teaching Staff View on Kazakhstan's Engineering and Information Technology Higher Education at Master Level. The 16th international conference "Social Innovations for Sustainable Regional Development": April 29, 2020. Abstracts of reports, 109-112. Klaipėda: Klaipėda University, 2020. 